IVANA DOBRIVOJEVIĆ, istraživač-saradnik

Institut za savremenu istoriju

UDK 316.728(497.11)"1945/1955"(093.2)

Beograd, Trg Nikole Pašića 11

316.343:631-051(497.11)"1945/1955"(093.2)

\title{
SLIKA JEDNOG DRUŠTVA. ŽIVOTNE PRILIKE NA SRPSKOM SELU 1945-1955.*
}

\begin{abstract}
APSTRAKT: Članak razmatra teške životne prilike na srpskom selu u prvoj deceniji posle Drugog svetskog rata, kao i izvesne, nesistematične i nedovoljne, napore vlasti koje su za cilj imali kulturno i zdravstveno-higijensko podizanje seoskog življa, a samim tim i unapređenje kulture življenja. Korišćeni su izvori iz Arhiva Jugoslavije, Arhiva Srbije i Arhiva Josipa Broza Tita.
\end{abstract}

Ključne reči: Selo, Srbija, stanovanje, ishrana, zdravstvena kultura, modernizacija

Prenaseljeno, siromašno, autarhično, gladno i neprosvećeno, srpsko selo je dočekalo revolucionarnu smenu vlasti. Rat i ratna stradanja, velike ljudske žrtve, materijalna razaranja, devastirana poljoprivreda i uništen stočni fond nadovezivali su se na vekovnu zaostalost i dodatno pogoršavali tegobne životne prilike. Konzervativni nazori i patrijarhalna shvatanja, insistiranje na starim navikama i pradedovskom iskustvu rezultirali su tvrdoglavim opiranjem seoskog stanovništva i najmanjim životnim promenama. Nužne modernizacijske procese započete 30-ih godina zaustavio je i presekao rat, a novi socijalistički režim, uprkos znatnim prosvetnim naporima i rezultatima naročito na planu zdravstveno-higijenskog podizanja, pred sobom je imao samo jednu viziju i jedan cilj - potpunu socijalističku transformaciju sela i konačan obračun sa seljaštvom, nosiocem „,sitnoposedničkih" shvatanja, „kapitalističkog“ načina privređivanja, baštinikom „starog“ društva i „starog“ sistema. U novom, komunističkom svetu u izgradnji, mesta za autarhično i u vremenu zaustavljeno selo nije bilo. Trebalo je stoga, bez milosti i preko noći, lomiti i kidati „ono što se stoljećima nagomilavalo" ${ }^{\text {"1 }}$, ideološki vaspitavati i seoskoj omladini predstavljati ,socijalizam i socijalističku demokratiju kao njenu budućnost i sreću“. ${ }^{2}$ Agrarna reforma, otkup, nasilna kolektivizacija,

* Rad je deo projekta Srpsko društvo u jugoslovenskoj državi u 20. veku-Između demokratije i diktature (177016), koji finansira Ministarstvo prosvete i nauke Republike Srbije.

${ }^{1}$ J. B. Tito, Govor na Trećem kongresu Saveza komunista Srbije (28. april 1954), Govori i članci, t. IX, Zagreb 1959, 136.

${ }^{2}$ Izlaganje Zdravka Vukovića, VI kongres Komunističke partije Jugoslavije (Saveza komunista Jugoslavije) 2-7. novembra 1952, Stenografske beleške, Beograd 1952, 298. 
zemljišni maksimum, prekomerno oporezivanje, zabrana prodaje imetka, politika cena, brutalni obračun sa „kulacima“ i svim onim koji su pokušali da se suprotstave nemilosrdnoj represiji - bile su samo neke od mera koje su pratile socijalističku modernizaciju. Iako je partijska politika na selu do sredine 1953. godine pretrpela fijasko, poljoprivredna proizvodnja i selo u celini već su doživeli slom od koga se nikada u potpunosti nisu oporavili.

Istorijske okolnosti, prirodno-geografske odlike, stepen ekonomske razvijenosti, nivo prosvećenosti, stopa nataliteta, kvalitet saobraćajnih komunikacija, blizina gradova, ali i broj gimnazista, studenata, pa čak i radnika - polutana, presudno su uticali na kulturni nivo seoskog stanovništva, određujući tako i kulturu življenja na srpskom selu. Stoga su republičke regionalne različitosti i neujednačenosti u pogledu životnog stila seljana bile ogromne. Vojvođanska starosedelačka sela, agrarni regioni oko Šapca i Valjeva, delovi Šumadije, pojedina sela u užičkom kraju i Moravskom srezu, ali i srpska i crnogorska kolonistička sela na Kosovu, predstavljali su primere čistoće i urednosti. Održavane kuće, okrečene i nameštene prostorije, uređena dvorišta i bašte sa cvećem, svakodnevno umivanje, nedeljno kupanje i relativno redovno presvlačenje, solidna briga o deci, spavanje u zasebnim krevetima, posedovanje dušeka i jorgana, upotreba povrća u ishrani, ostavljanje zimnice ali i korišćenje tanjira i escajga pri obedovanju ${ }^{3}$ približavali su ova sela gradskom životnom stilu i svedočili su o većoj kulturi i formiranim higijenskim navikama žitelja pojedinih delova Srbije. Kvalitet življenja je, po pravilu, opadao kako se išlo od severa ka jugu i od zapada ka krajnjem istoku, a plodni ravničarski krajevi su bili napredniji od brdsko-planinskih. Izuzetaka je naravno bilo, pa se u kolonističkim selima u Vojvodini i čitavu deceniju po preseljenju živelo daleko primitivnije nego u starosedelačkim. Međutim, čak ni život u relativno dobrostojećim i privredno naprednijim selima, koliko su već ondašnje političke prilike dopuštale, nije garantovao ništa više od pukog životarenja. Tako su u velikim selima oko Niša, u kojima su radile osmoljetke i progimnazije, a seljaci zemlju obrađivali na savremen način, kuće i dvorišta bila „vrlo prljava“ i zapuštena. ${ }^{4}$ Bilo je međutim i siromašnih, a uređenih sela, poput valjevskog Mainovića čiji su se stanovnici kulturno izdigli neposredno pred okupaciju, pre svega zahvaljujući obližnjoj zdravstvenoj stanici i domaćičkom kursu koji su pohađale seoske devojke. ${ }^{5}$

${ }^{3}$ Izveštaj o proučavanju problematike domaćinstva u selu Katun, sreza Moravskog, AJ, 141-13-70; Izveštaj ekipe iz sela Dupljaja, AJ-13-70; Izveštaj o obilasku sela Mainovića. O radu, životu i načinu uzdizanja domaćinstva, AJ, 141-13-70; Selo Ratkovac, AJ, 141-13-70; Izveštaj o proučavanju problematike domaćinstva u selu Prćilovci, sreza Moravskog; AJ, 141-13-70; Sastanak Glavnog odbora AFŽ Srbije od 4. jula 1952, AJ, 141-36-237; Izveštaj sreskog odbora AFŽ Prokuplje, AJ, 141-13-70; Dž. Halpern, Srpsko selo. Društvene i kulturne promene u seoskoj zajednici 1952-1987, Beograd 2006, 131-133.

${ }^{4}$ Sastanak Glavnog odbora AFŽ Srbije od 4. jula 1952, AJ, 141-36-237.

${ }^{5}$ Izveštaj o obilasku sela Mainovića. O radu, životu i načinu uzdizanja domaćinstva, AJ, $141-13-70$ 
Uprkos pobrojanim razlikama i regionalnim varijacijama, bedni stambeni uslovi, komunalna zapuštenost i nehigijena, bolesti kao posledica neznanja, velika smrtnost dece, loša ishrana, nečistoća tela i odela, sveopšta neprosvećenost i razne praznoverice činile su svakodnevicu najvećeg dela srpskog, ali i jugoslovenskog, seljaštva. Žalosno stanje na selu predstavljao je bremenito nasleđe Kraljevine Jugoslavije - rezultat siromaštva, neprosvećenosti, patrijarhalnih shvatanja ali i specifičnog mentalnog sklopa seljaka, osuđenih na život na zemlji i od zemlje, koji su daleko više brige i napora ulagali u unapređenje ekonomije svoga domaćinstva nego u uređenje životnog prostora i podizanje kvaliteta ličnog života. U uslovima u kojima je živeti značilo samo i jedino privređivati, seoski stanovi su zaostajali za već ionako niskim kulturnim i proizvodnim mogućnostima seljaštva. ${ }^{6}$ Stoga su neveseli pejsaž srpskog sela uglavnom činile niske i trošne kuće od ćerpiča i naboja, malih prozora i zemljanog poda, ${ }^{7}$ tesne, nedovoljno čiste i oskudno nameštene. Poneki krevet, stolica, šifonjer, šporet i improvizovana polica za suđe predstavljali su osnovni i jedini inventar većine skromno uređenih seoskih domova. ${ }^{8}$ Neokrečene, čađave, prašnjave, zapuštene prostorije, otvorena ognjišta, kao i odsustvo čak i najprimitivnijih toaleta bile su samo neke od slika seljačke svakodnevice. Najteže prilike su vladale na Kosovu i u Sandžaku gde seljačka neprosvećenost kao da nije imala granica. „60 godina od kako je naša kuća podignuta“, poverio se meštanin kosovskog sela Rašića ekipi Antifašističkog fronta (AFŽ), ,i na njoj nikada ni jedan prozor nije otvoren“. ${ }^{9}$ Štaviše, nisu bili retku ni slučajevi da su u istom prostoru obitavali i ljudi i stoka, ${ }^{10}$ a dešavalo se da se brojne porodice tiskaju u jednoj sobi, kako bi se u ostalim prostorijama napravilo mesta za stočnu hranu! $!^{11}$

Odsustvo svakog, pa čak i minimalnog osećaja za komfor i udobnost, uticao je na srpske seljake da ne koriste dovoljno i ono malo prostora i inventara koji su im u oskudno uređenim domovima stajali na raspolaganju. Svedenih potreba i ograničenih navika, seljak je sebe i svoju porodicu vazda stavljao na poslednje

${ }^{6}$ V. Zapisnik sa sastanka rukovodioca gradskih organizacija AFŽ-a za Vojvodinu koji je održan 1. marta 1952, AJ, 141-36-240.

${ }^{7}$ Prema zvaničnim statističkim podacima iz 1955. godine, čak $64,1 \%$ seoskih domova u Srbiji bilo je sagrađeno od zemljanog naboja ili ćerpiča, a 71,3\% kuća imalo je zemljani pod. Podaci o kvalitetu prostorija za stanovanje seoskih domaćinstava u procentima (podaci iz 1955. godine), AJ, 114-96.

${ }^{8}$ Problemi seoskog domaćinstva u srezu Borskom, AJ, 141-13-70; Izveštaj o obilasku sela Mainovića. O radu, životu i načinu uzdizanja domaćinstva, AJ, 141-13-70; Izveštaj sreskog odbora AFŽ Vladičin Han, AJ, 141-13-70.

${ }^{9}$ Izveštaj o radu I ekipe Centralnog odbora AFŽ Jugoslavije za zdravstveno prosvećivanje žena Šiptarki, koja je radila u Pećkom srezu od 23. 4. do 23. 5. 1951, AJ, 141-33-183.

${ }^{10}$ Б. М. Томић, Хигијенски проблеми села (Босиљградски срез), Београд 1954, 22.

${ }^{11}$ Izveštaj o radu V zdravstvene ekipe Centralnog odbora AFŽ-a, AJ, 141-33-184; Izveštaj o radu I ekipe Centralnog odbora AFŽ Jugoslavije koja je radila na prosvećivanju žena Šiptarki u Pećkom srezu od 23. aprila do 23. maja 1951, AJ, 141-33-184; Izveštaj o radu ekipe Centralnog odbora AFŽ Jugoslavije za zdravstveno prosvećivanje žena koja je radila od 20. juna do 20. jula ove godine, AJ, 33-184. 
mesto. Prednost je davana nenadanim gostima ili čak poljoprivrednom inventaru, pa je život porodice, bez obzira na broj članova, čak i u bogatijim domaćinstvima, bio ograničen samo na jednu prostoriju. ${ }^{12}$ Seljane je bilo gotovo nemoguće ubediti da koriste i gostinjske sobe, pa o zdravlju i higijeni, ali i intimi i privatnosti u seoskim domovima nije moglo biti ni reči, niti se za njih mnogo marilo. Noćivalo se u zajedničkim krevetima, obično po troje-četvoro u jednom, ${ }^{13}$ ali i na slamaricama i asurama na podu. ${ }^{14}$ Neoprana i pocepana posteljina, ${ }^{15}$ kakva ponjava od vune ${ }^{16}$ ili samo , „̌erga“ ${ }^{17}$ upotpunjavali su sliku nezdravog i nehigijenskog spavanja. Deca su spavala zajedno sa roditeljima, ali i sa babama i dedama, čak i u onim kućama gde je bilo uslova da spavaju odvojeno, uz obrazloženje da su „tako naučila“ i , „da neće sama“. ${ }^{18}$ Bilo je i drastičnijih slučajeva. U selu Kržnice, nedaleko od Vladičinog Hana, roditelji su spavali na krevetima, a deca na zemlji na rogoži! ${ }^{19}$ Ipak, primitivna porodična hijerarhija bila je najizraženija u u kosovskim selima nastanjenim srpskim življem u kojima su žene i deca, u skladu sa svojim položajem u domaćinstvu, noćivali po izbama, zapravo podrumima bez prozora ili sa vrlo malim prozorima, vlažnim i natrpanim buradima sa rakijom i kiselim kupusom. ${ }^{20}$

Oproban obrazac ,štednje“ i ,čuvanja“, jasno demonstriran na primeru nepotpunog korišćenja raspoloživih kućnih prostorija, ponavljao se do unedogled i u ostalim segmentima kućnog života. Što zbog oskudice, što zbog neznanja, a što zbog prikraćivanja i štednje, ishrana je bila svedena i jednolična. Živelo se na hlebu, krompiru, mlečnim proizvodima, pasulju i luku, ${ }^{21}$ a meso je, čak i u bogatijim i naprednijim selima, relativno retko korišćeno. ${ }^{22}$ Seljaci za kvalitet obroka nisu mnogo marili, budući da je jedino važno bilo napuniti stomak. Razlika u ishrani bogatijih i siromašnijih porodica jedva da je i postojala, a oni seljaci koji su svoje proizvode iznosili na pijacu nastojali su da „prištede“ na sopstvenim potrebama, kako bi najbolju voćku ili jaja prodali. ${ }^{23}$ Umešnost žena u kuhinji je varira-

${ }^{12}$ Zapisnik sa sastanka rukovodilaca gradskih organizacija AFŽ-a za Vojvodinu koji je održan 1. marta 1952, AJ, 141-36-240; Izveštaj sreskog odbora AFŽ Prokuplje, AJ, 141-13-70.

${ }^{13}$ Problemi seoskog domaćinstva u srezu Borskom, AJ, 141-13-70; Sastanak Glavnog odbora AFŽ-a od 4. jula 1952, AJ, 141-36-237.

${ }^{14}$ Izveštaj o radu V zdravstvene ekipe Centralnog odbora AFŽ-a, AJ, 141-33-184.

${ }^{15}$ Izveštaj higijensko-zdravstvene ekipe za Bačko Novo Selo, AJ, 141-33-184.

${ }^{16}$ Problemi seoskog domaćinstva u srezu Borskom, AJ, 141-13-70.

${ }^{17}$ Izveštaj o proučavanju problematike u Bujmiru - sreza Moravskog, AJ, 141-13-70.

${ }^{18}$ Izveštaj higijenske zdravstvene ekipe koja je bila u Brestacu i D. Tovarniku, srez Ruma, 30. oktobar -7. novembar 1951, AJ, 141-33-183.

${ }^{19}$ Izveštaj sreskog odbora AFŽ Vladičin Han, AJ, 141-13-70.

${ }^{20}$ Izveštaj o radu II ekipe Centralnog odbora AFŽ-a Jugoslavije za zdravstveno prosvećivanje žena Šiptarki, koja je bila na terenu Kosovske Mitrovice 28 dana, AJ, 141-33-187.

${ }^{21}$ Život, rad i problematika seoskog domaćinstva, AJ, 141-13-70.

${ }^{22}$ Dž. Halpern, Srpsko selo. Društvene i kulturne promene u seoskoj zajednici 1952 1987, Beograd 2006, 132.

${ }_{23}$ А. Ђаја, Прилог познавању исхране на селу. Исхрана села Прилике, Београд 1955, $31-34,68$. 
la od kraja do kraja, a većina seljanki je umela da pripremi tek najjednostavnija jela, budući da se kuvanju na srpskim selima pridavala minimalna pažnja. Usled slabe i nepravilne ishrane, deca u bogatom Mačvanskom srezu su izgledala kao „kosturi neuhranjeni““ ${ }^{24}$ Seosko stanovništvo se uporno držalo stečenih navika u ishrani, pa su i povrtarska sela koja su snabdevala Beograd živela isključivo na pasulju, luku, krompiru i paradajzu. Ostalo povrće - tikvice, kelj, spanać i šargarepu proizvodili su jedino radi prodaje. Sami ga uglavnom nisu trošili, budući da ni žene nisu umele da ga spreme. ${ }^{25}$

Iako je zemljanog i emajliranog posuđa, ali i porculanskih tanjira, u mnogim seoskim kućama bilo sasvim dovoljno, cela porodica je, kao po nekom pravilu, bez obzira na nivo prosvećenosti i ekonomsku snagu domaćinstva, obedovala iz jedne zdele, dok su tanjiri i čaše iznošeni samo na slavama i drugim svetkovinama. ${ }^{26}$ Zdravstvene ekipe su čak i po selima na Kosovu nailazile na „dosta emajliranog posuđa“ koje je nepravilno upotrebljavano. „Tako se na primer u noćnu posudu stavljala hrana, lavor je služio kao činija, a u emajliranom bakraču su držane splačine za stoku... dok je mleko kuvano u zarđaloj kanti“. Hrana je zahvatana tiganjem, iako je bilo emajliranih lončića. ${ }^{27} \mathrm{O}$ bilo kakvoj higijeni, čak ni pri pripremanju jela, u mnogim krajevima nije bilo ni govora. Zarđale kašike, prašnjave šerpe i činije okačene na zidu činile su oskudni kuhinjski inventar domaćinstva zaostalog prokupačkog sela Kruševica. ${ }^{28}$ Slično se živelo i u vojvođanskim kolonističkim selima naročito onim koja su, poput Brestovca i Bačkog Novog Sela, bila naseljena življem iz Sandžaka, južne i istočne Srbije. Hrana je pripremana prljavim rukama, na mesecima nepočišćenim stolovima i u neopranim sudovima. ${ }^{29} \mathrm{Na}$ još teže životne prilike, usled zaostalosti i neznanja, bili su osuđeni stanovnici sela Istinić i Barane koji su posuđe prali u kanalima - jazovima, po pravilu zagađenim ,izmetom i drugom nečistoćom“. ${ }^{30}$

Neznanje i neprosvećenost, odsustvo ma kakve potrebe za lepšim, udobnijim i humanijim življenjem, ali i obaveze žene u svakodnevnom privređivanju, uticale su da briga o čistoći i urednosti domaćinstva večito bude na poslednjem mestu. Izgovor i opravdanje za sveopštu nehigijenu u zaostalim selima uvek je bio isti - nedostatak vremena usled preopterećenosti poljoprivrednim radovima. ${ }^{31}$ Neprovetrene prostorije, prašnjavi domovi puni vašiju i stenica, ${ }^{32}$ neodržavani i

${ }^{24}$ Sastanak Glavnog odbora AFŽ-a od 4. jula 1952, AJ, 141-36-237.

25 А. Ђаја, Прилог познаваюу исхране на селу. Исхрана села Прилике, Београд $1955,13$.

${ }^{26}$ Sastanak Glavnog odbora AFŽ Srbije od 4. jula 1952, AJ, 141-36-237.

${ }^{27}$ Izveštaj o radu I ekipe Centralnog odbora AFŽ Jugoslavije za zdravstveno prosvećivanje žena Šiptarki, koja je radila u Pećkom srezu od 23. 4 do 23. 5. 1951, AJ, 141-33-183.

${ }^{28}$ Izveštaj sreskog odbora AFŽ Prokuplje, AJ, 141-13-70.

${ }^{29}$ Izveštaj higijensko-zdravstvene ekipe za Bačko Novo Selo, AJ, 141-33-184.

${ }^{30}$ Izveštaj o radu I ekipe Centralnog odbora AFŽ Jugoslavije za zdravstveno prosvećivanje žena Šiptarki, koja je radila u Pećkom srezu od 23. 4 do 23. 5. 1951, AJ, 141-33-183.

${ }^{31}$ Izveštaj sreskog odbora AFŽ Prokuplje, AJ, 141-13-70.

${ }^{32}$ Zapisnik sa sastanka Pokrajinskog odbora AFŽ-a od 20. juna 1952, AJ, 141-36-240. 
izriveni patosi,${ }^{33}$ nepočišćena dvorišta, ${ }^{34}$ rasturena đubrišta, ${ }^{35}$ stvari razbacane na sve strane ${ }^{36}$ neodvojene pomoćne poljoprivredne zgrade, ${ }^{37}$ zapušteni bunari i kladenci, ${ }^{38}$ na brzinu i u hladnoj vodi proprano rublje ${ }^{39}$ predstavljali su stoga jedini poznati životni ambijent u velikom broju srpskih sela. Na nehigijenu doma i primitivan način života nadovezivala se nehigijena tela, zatvarajući tako začarani krug neukosti, bolesti, bede i mizerije. Mnogi seljani su, što zbog neznanja, što zbog lenjosti, redovno ,preskakali“ umivanje, kupanje i češljanje, ${ }^{40}$ a o održavanju higijene usta i zuba nije bilo reči čak ni u naprednijim i urednijim kućama. ${ }^{41}$ Mlade Albanke na Kosovu su sve do udaje bile osuđene na život u prljavštini i mizeriji. Vašljive, nepočešljane, prljave i pocepane odavale su utisak skoro „divljih stvorenja“ budući da se verovalo je „sramota da devojka bude uredna“. Dešavalo se tako da se „,devojka prvi put okupa, očešlja i pristojno obuče kad treba da se uda““ ${ }^{42}$

Briga o deci u zaostalim selima bila je ravna brizi i trudu o čitavom domaćinstvu. „Uz svaku peć čuči po jedna prljava baba i u krilu drži još prljavije unuče“, rezignirano je primećeno u jednom izveštaju. ${ }^{43}$ Zapuštena, prljava, nepodšišana a katkad i vašljiva deca, trčala su u ritama po neuređenim seoskim dvorištima. ${ }^{44}$ Nemar i nebriga su dodatno otežavali ionako bedne ekonomske prilike i nestašicu tekstila, pa su deca, iako je vunenih čarapa bilo, u školu išla bo$\mathrm{sa}^{45}$ noseći umesto kaputa tri-četiri tesna, okrpljena džempera bez dugmadi. ${ }^{46} \mathrm{Na}$ (ne)brigu i zanemarivanje dece uticala je i patrijarhalna porodična hijerarhija, izražena u planinskim selima oko Ivanjice. Život u skladu sa konzervativnim normama značio je odgajanje dece u najsurovijim uslovima. Obespravljeni i zanemareni, najmlađi članovi porodice su odrastali „goli i bosi“, dok se deveru ostavljalo „najbolje“ odelo, a slični žalosni obrasci su ponavljani čak i prilikom ishrane! $!^{47}$ Nikakva pažnja nije posvećivana ni novorođenčadima, pa ekipi AFŽ-a po-

${ }^{33}$ Izveštaj o radu zdravstvene ekipe u Brestovcu u vremenu od 29. oktobra do 10. novembra 1951, AJ, 141-33-184; Izveštaj o radu V zdravstvene ekipe Centralnog odbora AFŽ-a, AJ, 14133-184.

${ }^{34}$ Izveštaj sreskog odbora AFŽ Vladičin Han, AJ, 141-13-70.

${ }^{35}$ Izveštaj o proučavanju problematike domaćinstava u selu Rsovcu, sreza Moravskog, AJ, 141-13-70; А. Ђаја, Прилог познавању исхране на селу. Исхрана села Прилике, 11; С. Коstić, Bor i okolina, Beograd 1962, 106.

${ }^{36}$ Izveštaj higijensko-zdravstvene ekipe za Bačko Novo Selo, AJ, 141-33-184.

${ }^{37}$ Problemi seoskog domaćinstva u srezu Borskom, AJ, 141-13-70.

${ }^{38}$ Informacije o radu sekcija žena AFŽ od 12. marta 1952, AS, Đ 2-16-4.

${ }^{39}$ Izveštaj higijensko-zdravstvene ekipe za Bačko Novo Selo, AJ, 141-33-184.

${ }^{40}$ Zapisnik sa sastanka Pokrajinskog odbora AFŽ-a od 20. juna 1952, AJ, 141-36-240.

${ }^{41}$ Izveštaj sreskog odbora AFŽ Vladičin Han, AJ, 141-13-70.

${ }^{42}$ Izveštaj o radu I ekipe Centralnog odbora AFŽ Jugoslavije za zdravstveno prosvećivanje žena Šiptarki, koja je radila u Pećkom srezu od 23. 4 do 23. 5. 1951, AJ, 141-33-184.

${ }^{43}$ Informacije o radu sekcija žena AFŽ od 12. marta 1952, AS, Đ 2-16-4.

${ }^{44}$ Isto.

${ }^{45}$ Izveštaj higijensko-zdravstvene ekipe za Bačko Novo Selo, AJ, 141-33-184.

${ }^{46}$ Informacije o radu sekcija žena AFŽ od 12. marta 1952, AS, Đ 2-16-4.

${ }^{47}$ Sastanak Glavnog odbora AFŽ-a od 4. jula 1952, AJ, 141-36-237. 
sle posete Bačkom Novom Selu nije ostalo ništa drugo nego da konstatuje da je „pravo čudo kako deca i u ovom broju ostaju u životu“. ${ }^{48}$ Neznanje i neprestan strah od hladnoće uticali su na seljane da decu utopljavaju preko svake mere, ${ }^{49}$ a kolevke prekrivaju kakvim ćebetom ili ćilimom, tako da odojčad nisu uopšte imala vazduha. ${ }^{50}$

Dramatična situacija je vladala u kosovskim selima, kako kod srpskog tako i kod albanskog stanovništva, u kojima su praznoverice oblikovale životni stil i krojile (ne)higijenske navike. Mališani su odgajani u malim i primitivnim kolevkama, „kalupima“, koji su podsećali na korito izdubljeno od debla drveta, ${ }^{51}$ a od uroka „,branjeni“ amajlijama. Verovalo se i da decu do prve godine ne treba ni češljati ni šišati, niti im nokte podrezivati, kako se, kad porastu, ne bi odala krađi. ${ }^{52}$ Meštani Bijelog Polja, srpskog sela u blizini Peći, smatrali su da deci ne treba prati uši da se ne bi usled strujanja hladnog vazduha kroz njih razbolela od upale pluća! ${ }^{53}$ Odgajana u bedi i neznanju, deca su ispitivala svet oko sebe stavljajući u usta sve što su nalazila. ${ }^{54}$ Zaostalost majki nije imala granica, pa se dešavalo da žena iz pojasa izvadi parče hleba, sažvaće ga i pruži detetu ${ }^{55}$ ili pak u školsku torbu, zajedno sa hranom, stavi i malo rakije da se nađe detetu! ${ }^{56}$ Surovo detinjstvo imalo je svoje posledice, pa su i ona deca koja su uspevala da prežive u ovakvim uslovima bila nejaka i bolešljiva. Tako je ekipa AFŽ-a prilikom prosvetnog rada u Pećkom srezu u leto 1951. godine procenila da je čak 97\% mališana bilo rahitično i anemično, budući da su danima živeli na luku, soku od sira, hlebu i mleku razblaženom vodom. ${ }^{57}$

Primitivnost i zaostalost seoskog života ne samo da je narušavala komoditet stanovništva već se direktno odražavala na opšte zdravstveno stanje, određivala životni vek i uzrokovala veliku smrtnost, naročito dece i odojčadi. Epidemije tifusa, rekurensa, difterije, dizenterije koje su periodično izbijale, naročito u prvim godinama posle oslobođenja, ali i endemijski sifilis, predstavljale su direktnu posledicu sveopšte nehigijene, kako komunalne, tako i lične. Zagađenost bunara i njihove okoline, nepostojanje kanalizacione i vodovodne mreže, korišćenje jedne zdele pri obrocima, vašljivost i neredovno održavanje higijene ruku i tela, kao i spavanje u zajedničkoj postelji sa bolesnicima - bili su samo neki od

${ }^{48}$ Izveštaj higijensko-zdravstvene ekipe za Bačko Novo Selo, AJ, 141-33-184.

${ }^{49}$ Problemi seoskog domaćinstva u srezu Borskom, AJ, 141-13-70.

${ }^{50}$ Izveštaj higijensko-zdravstvene ekipe za Bačko Novo Selo, AJ, 141-33-184.

${ }^{51}$ Почела је борба против незнања и заосталости, Жена данас, 83, 1951.

52 Izveštaj o radu II ekipe Centralnog odbora AFŽ-a Jugoslavije za zdravstveno prosvećivanje žena Šiptarki koja je bila na terenu Kosovske Mitrovice 28 dana, AJ, 141-33-184.

${ }^{53}$ Izveštaj o ispitivanju uzroka dečijih oboljenja u srezu Pećkom u vremenu od 10-17. jula ove godine, AJ, 141-33-188.

${ }^{54}$ V. і Р. Боројевић, Из Дубиа у свет, Београд 1964, 8.

${ }^{55}$ Почела је борба против незнања и заосталости, Жена данас, 83, 1951.

${ }^{56}$ Р. Боројевић, Из Дубияа у свет, 63.

${ }^{57}$ Izveštaj o ispitivanju uzroka dečijih oboljenja u srezu Pećkom u vremenu od 10-17. jula ove godine, AJ, 141-33-188. 
uzročnika i „krivaca“ katastrofalnog zdravstvenog stanja po srpskim selima. Ekonomske prilike i veliko siromaštvo, uz nepostojanje osnovnih higijenskih navika pri spavanju i ishrani, doprinosili su nezaustavljivom širenju tuberkuloze, socijalne bolesti koja je u prvoj posleratnoj deceniji harala srpskim selom jačim intenzitetom nego u Kraljevini Jugoslaviji. ${ }^{58}$ Sujeverje, nadrilekari, bajalice i svakovrsne praznoverice carovale su na srpskim selima. Čvrsto ubeđen u fatalizam i predodređenost, seoski živalj se u potpunosti prepuštao sreći i sudbini. „Lečenja“ konjskim kopitima i kokošijim đubretom, provlačenjem ispod manastirske loze ili „salivanjem strave“ predstavljala su samo neke od seoskih „,zdravstvenih“ metoda. ${ }^{59}$ Vračanjem su ,isceljivani“ uroci, strah, nesanica, glavobolja, razne rane i kožna oboljenja, ${ }^{60}$ a čak su i situirani seljaci iz Junkovca nedaleko od Topole bolesnoj deci radije „privezivali miša“, nego što su se za pomoć obraćali lekaru. ${ }^{61}$ Još strašniji običaji vladali su u podunavskom selu Kostol u kome su meštani „skupljali pljuvačku“ i njome lečili bolesnike!? ${ }^{62}$

Loša higijena u trudnoći, mukotrpan rad do samog porođaja, nehigijenski uslovi rađanja i nepoznavanje osnovnih pravila u odgajanju i podizanju dece uticali su da smrtnost najmlađih u pojedinim delovima Jugoslavije i Srbije bude među najvećim u svetu. ${ }^{63}$ Meštani zaostalih sela, navikli na neprestano umiranje, sa stoičkom rezigniranošću su prihvatali dečiju smrtnost, uveravajući zdravstvenoprosvetne ekipe da se tu ništa ne može, da dece ,ima dosta, a biće ih još““ ${ }^{64}$ Odmah po rođenju, novorođenčad su čekale životne nedaće - prljava krpa ili slama na kojoj je dolazilo na svet, presecanje pupčane vrpce srpom, nožem, zarđalim makazama ${ }^{65}$ kosom ili zubima, podvezivanje pupka koncem ili komadićem stare, trule krpe, posipanje pupčane rane paučinom i povijanje u neoprane krpe ${ }^{66} \mathrm{hra}-$ njenje đubrištem sa bunjišta ,da bi dete jelo sve što mu se da“ ${ }^{67}$ Neumitna posledica toga bila je ogromna smrtnost već u prvim danima po rođenju. Umiranje najmlađih je pogađalo i bogatije i siromašnije krajeve, kako prosvećena tako i neprosvećena sela. „Na Kosmetu svaki drugi grob je grob deteta do deset godina, u Vojvodini svaki treći, a u Srbiji svaki šesti“, pisala je Borba polovinom 1954. go-

${ }^{58}$ Stenografske beleške Plenuma stručnog saveta pri Komitetu za zaštitu narodnog zdravlja FNRJ održanog 15. decembra 1947. godine, AJ, 31-3-5.

${ }^{59}$ Problem ustaljenih spoznaja. Prilog metodici zdravstvenog prosvećivanja, AJ, 31-96-

137.

${ }^{60}$ Izveštaj sreskog odbora AFŽ Prokuplje, AJ, 141-13-70, Dž. Halpern, Srpsko selo. Društvene i kulturne promene u seoskoj zajednici 1952-1987, 201.

${ }^{61}$ Sastanak Glavnog odbora AFŽ-a od 4. jula 1952, AJ, 141-36-237.

${ }^{62}$ Stenografske beleške sa sastanka održanog u CK SKS u Beogradu 2. juna 1953, AS, Đ2-7 (Sastanci CK SK Srbije po raznim pitanjima) - 2 .

${ }^{63}$ V. і Д. Тасић, Смртност одојчади у Југославији, Београд 1955, 5; М. С. Kaser, Е.

A. Radice, The Economic History of Eastern Europe 1919-1975, t I, Oxford 1975, 352-353.

${ }^{64}$ Izveštaj higijensko-zdravstvene ekipe za Bačko Novo Selo, AJ, 141-33-184.

${ }^{65}$ Oboljevanje i smrtnost matera i njihovi uzroci u FNRJ, AJ, 141-33-187.

${ }^{66}$ Izveštaj higijensko-zdravstvene ekipe za srez Kopaonički, AJ, 141-33-184.

${ }^{67}$ Сујеверје - урок разних болести у нашим селима, Омладина, 5. новембар 1952. 
dine. ${ }^{68}$ Između stalnih smena ciklusa rađanja i umiranja u jednoj porodici, niko osim majke nije tačno znao koliko je dece u kući rođeno, a koliko je umrlo. U zaostalim kosovskim selima čak su majke govorile: „Imala sam ih jedno šestero sedmero, a umrlo je troje - četvoro" ". ${ }^{69}$ Tačne podatke o smrtnosti dece, naročito na Kosovu i Metohiji, nisu imale ni vlasti, budući da su neprijavljena novorođenčad ,zakopavana u dvorištu, ispod kakvog drveta“. ${ }^{70}$

Suočene sa ogromnom smrtnošću dece i velikim epidemijama koje su odnosile na hiljade života, nove vlasti su pristupile higijenskom i zdravstvenom prosvećivanju masa, pre svega preko Komiteta za narodno zdravlje ${ }^{71}$ ali i masovnih organizacija kao što su AFŽ, Narodni front i SKOJ. Najveći rezultati su postignuti u suzbijanju zaraznih bolesti - pegavca, rekurensa, malarije, trahoma, mikoza, endemijskog sifilisa i raznih stomačnih oboljenja. ${ }^{72}$ Kako je popravljanje zdravstvenog stanja stanovništva ozbiljno narušenog životnim prilikama i ratnim razaranjima bilo nezamislivo bez širokog higijenskog prosvećivanja, vlasti su, doduše nedovoljno sistematski, pokušavale da kulturno podignu seoski živalj putem predavanja, filmova, ${ }^{73}$ brošura, izložbi, plakata $^{74} \mathrm{i}$,političkog objašnjavanja“ mera zdravstveno-prosvetnog rada. Analfabetski tečajevi, domaćički i drugi kursevi, radne akcije, ali i Jugoslovenska armija su takođe služili kao svojevrsni „medijumi“ za prenošenje i usađivanje higijenskih i drugih kulturnih navika koje su bile jedan od osnovnih preduslova modernizacije i kvalitetnijeg življenja. Ipak, sveopštu zaostalost nije bilo lako iskoreniti, a zamišljene akcije isušivanja močvara, kanalisanja korita, obezbeđivanja zdrave pijaće vode, podizanja novih stambenih prostorija, pravljenja štala, otvaranja većih prozora, izrade kreveta, ${ }^{75}$ zidanja higijenskih toaleta ${ }^{76}$ i planske izgradnje i uređenja sela ${ }^{77}$ - osim deklarativnog entuzijazma iskazivanog u raznim uputstvima, projektima i planovima zahtevale su znatna materijalna sredstva, veća ulaganja u poljoprivredu i napuštanje nerealnih industrijalizacionih planova. Iako su partijski funkcioneri neprestano snevali o pomeranju granica mogućeg, manjak materijalnih sredstava, a pre svega nedostatak školovanih i prosvećenih ljudi, kombinovan sa širokim ali ipak povremenim radom i sporadičnim naporima, onemogućavao je suštinske promene i istinsku modernizaciju. Uprkos stalnim deklarativnim zalaganjima za kultur-

${ }^{68}$ Како спасти животе 40000 деще, Борба, 18. јули 1954.

${ }^{69}$ Izveštaj o radu II ekipe Centralnog odbora AFŽ-a Jugoslavije za zdravstveno prosvećivanje žena Šiptarki, koja je bila na terenu Kosovske Mitrovice 28 dana, AJ, 141-33-187.

${ }^{70}$ Izveštaj o zdravstvenom stanju naroda i zdravstvenoj službi, AJBT, KPR II-7-a.

${ }^{71}$ Kratak pregled rada Komiteta za zaštitu narodnog zdravlja vlade FNRJ u 1946. godini, AJ, 31-1-2. AJ, 31-21-41.

${ }^{72}$ Kratak izveštaj o radu higijensko-epidemiološkog sektora za zaštitu narodnog zdravlja,

${ }^{73}$ Organizacija kampanje za likvidaciju endemijskog sifilisa, AJ, 31-25-42.

${ }^{74}$ Prosvećivanje seoskih žena, AJ, 141-15-80.

${ }^{75}$ Narodni front, AS, Đ 75-32.

${ }^{76}$ Br. 324 od 22. januara 1948, AS, Đ2-16-2.

${ }^{77}$ Pitanje planske izgradnje sela u Srbiji, AJ, 13-106. 
no-zdravstveno podizanje i prosvećivanje seoskog življa, vlasti su daleko više napora ulagale $\mathrm{u}$ ideološko vaspitanje nego u praktične higijenske akcije. ${ }^{78}$ „Zdravstveno prosvećivanje nije bilo provođeno po nekom sistemu i planu, nego kampanjski“, čulo se na međurepubličkoj konferenciji zdravstvenih radnika. Sistematski napori su izostajali, a prosvećivanje se uglavnom svodilo na organizovanje prigodnih zdravstvenih nedelja i povremene aktivnosti masovnih organizacija koje nisu mogle dati željene rezultate i dovesti do očekivanog napretka. ${ }^{79}$ Paradoksalno, u pojedinim krajevima izostajale su i prosvetne aktivnosti za koje nisu bila potrebna gotovo nikakva novčana sredstva niti posebna organizacija i pripreme. Tako su u Mačvanskom srezu, uprkos higijensko-zdravstvenim problemima, od oslobođenja pa do 1950. godine održana svega dva predavanja! $!^{80}$

Partijsku zdravstveno-higijensku politiku ograničavale su i objektivne okolnosti - nedostatak sapuna, lekova, ${ }^{81}$ lekara i bolničkih kapaciteta. ${ }^{82}$ Svaki, pa i najmanji modernizacijski napori sprovođeni „odozgo“, po diktatu i želji vlasti, morali su nailaziti i na otpore usled neukosti stanovništva. Iako su mere suzbijanja zaraznih bolesti davale rezultate, trebalo je uložiti mnogo truda i seosko stanovništvo obolelo od sifilisa nagovoriti da se skine pred lekarom ${ }^{83}$ ili pak da prihvati BSŽ vakcinaciju dece. ${ }^{84}$ Težak ekonomski položaj, rđave stambene prilike, čvrsto ukorenjene predrasude i praznoverni narodni običaji i verovanja predstavljali su glavne ,protivnike“ vlastima u naporima za prosvećivanje masa. U ruralnim sredinama uloga nosioca modernizacije pripadala je nižim organima vlasti koji se po svojim shvatanjima, navikama i životnom stilu nisu ni najmanje razlikovali od ostalog seoskog življa. Stoga ni lokalni partijski funkcioneri nisu imali dovoljno razumevanja za zdravstveno-higijenske kampanje, pa se u selima Pančevačkog sreza verovalo da su aktivistkinje AFŽ-a ,žene koje nemaju pametnijeg posla“. ${ }^{85}$ Poverenici za narodno zdravlje su, gotovo po pravilu, korišćeni u „važnijim“ akcijama - obaveznom otkupu, organizaciji snabdevanja, naplati pore$\mathrm{za}^{86}$ setvenim kampanjama i slično. Sredstva iz budžeta namenjena kulturnom podizanju stanovništva lokalne vlasti na Kosovu nisu ni koristile, ${ }^{87}$ a dešavalo se da se štabovi formirani sa ciljem olakšavanja i omogućavanja rada zdravstveno-

${ }^{78}$ Kursevi za zdravstveno prosvećivanje seoske ženske omladine, AJ, 31-96-137.

${ }^{79}$ Zapisnik sa II međurepublikanske konferencije za zdravstveno prosvećivanje održane u Zagrebu 8-9. juna 1950, AJ, 31-96-137.

${ }^{80}$ Izveštaj o radu partijske organizacije sreza Mačvanskog - Bogatić, AS, Đ 4-30.

${ }^{81}$ Distribucija lekova, AJ, 31-8-22.

${ }^{82}$ Informativni izveštaj o zdravstvenoj službi u 1948. godini, A JBT, KMJ II-5-a-15.

${ }^{83}$ Uputstva zdravstvenim radnicima mjesnih narodnih odbora i terenskim ekipama za akciju suzbijanja endemijskog sifilisa, AJ, 31-25-42.

${ }_{84}$ Vakcinacija dece od 0-18 godina bsg-om u saradnji sa UNICEF- om, AJ, 31-87-128; Br. 403 od 1. aprila 1950, AJ, 31-87-128.

${ }^{85}$ Zapisnik sa sastanka sreskog komiteta KPS Pančevo održanog 25. marta 1952, IAP, 319-66.

${ }^{86}$ Izveštaj o radu V zdravstvene ekipe Centralnog odbora AFŽ-a, AJ, 141-33-184.

${ }^{87}$ Izveštaj sa puta u Kosovsku Kamenicu i Prištinu, AJ, 141-33-184. 
higijenskih ekipa uopšte i ne angažuju. ${ }^{88}$ Čak su i republička ministarstva trgovine ignorisala pojedine odredbe saveznog Ministarstva trgovine i snabdevanja. Opšta nestašica sapuna značajno je uticala na (ne)održavanje lične higijene, a novinske redakcije su uglavnom odbijale da publikuju poučne članke o štetnosti pljuvanja po podu, načinima prenošenja zaraznih bolesti i slično, insistirajući na vestima o uspesima zdravstvene službe. ${ }^{89}$

Uviđajući da je prosvećivanje seoske žene glavni i jedini uslov, ali i garant napuštanja tradicionalnog životnog stila i modernizacije domaćinstva, vlasti su, kopirajući donekle praksu i iskustva iz međuratnog perioda, pristupile otvaranju velikog broja domaćičkih tečajeva sa ciljem da ženu nauče ,kako se kuvaju dobra, raznovrsna i ukusna jela, kako se sprema zimnica, čuva i neguje zdravlje, održava čistoća, vaspitava i odgaja dete, neguje bolesnik i porodilja, uređuje kuća“. ${ }^{90}$ Ne vodeći računa o stvarnim potrebama, interesovanjima i limitima seoskih devojaka i njihovih porodica, prosvetne vlasti su pokušavale da tečajkama na stalnim petomesečnim ili pokretnim tromesečnim kursevima prenesu opšte obrazovanje „u obimu osnovne škole“, osposobe ih za dobre domaćice i nauče ručnim radovima. Preambiciozno zamišljen i nefleksibilan nastavni program nije vodio previše računa ni o agrarnim specifičnostima pojedinih ruralnih regiona, pa su seljanke slušale predavanja i iz živinarstva, mlekarstva, pčelarstva, svilarstva, voćarstva, lekovitog bilja, cvećarstva i povrtarstva. ${ }^{91}$ Navikli na bedne uslove života i okupirani poljoprivrednim radovima, mnogi seljaci su na domaćičke tečajeve gledali „kao na neku gospodsku besposlicu“. ${ }^{92}$ Uspeh tečajeva je varirao od kraja do kraja, a seljani su različito reagovali na mogućnosti unapređenja kulture življenja. Prosvetne aktivnosti u apatinskim selima dovele su do ujednačavanja životnih prilika između starosedelaca i kolonista, ${ }^{93}$ dok su u Larazevu, uprkos istim naporima, rezultati izostali. ${ }^{94}$ Međutim, konzervativizam u shvatanjima i navikama, kao i istrajavanja na pradedovskom iskustvu, uzrokovao je velike otpore bilo kakvim novinama i izmenama životnog stila, pre svega u najzaostalijim regionima Srbije. Domaćički tečajevi nisu stoga garantovali da će naučeno znanje biti i primenjeno, budući da se i 1956. godine dešavalo da devojke, zbog otpora starijih ukućana, nastavljaju da vode domaćinstvo na generacijama oproban, tradicionalan način. ${ }^{95}$

${ }^{88}$ Akcija zdravstvenog prosvećivanja u srezu Zvečanskom, AJ, 141- 33-183.

${ }^{89}$ И. Добривојевић, Прилог проучаваюу здравствене културе у Југославији 1945 1955, Историја медицине, фармације и народне медицине, зборник, Београд 2007, 136.

${ }^{90}$ Plan i program na privremenim tečajevima za prosvećivanje žene na selu, AJ, 313 (Ministarstvo prosvete vlade FNRJ) - 11-37.

${ }_{91}$ AJ, 317 (Savet za nauku i kulturu vlade FNRJ) - 58-81.

${ }^{92}$ Р. Боројевић, Из Дубиа у свет, 39.

${ }^{93}$ Izveštaj o službenom putovanju od 6. do 9. maja 1950. godine u Apatin po pitanju domaćičko-prosvetnih kurseva i u Novi Sad po pitanju dnevnih dečijih izletišta na Dunavu, AJ, 141-13-70.

${ }^{94}$ Zapisnik sa održanog sastanka Pokrajinskog odbora AFŽ-a od 20. juna 1952. godine, AJ, 141-36-240.

${ }^{95}$ Neki materijali o kulturno-prosvetnoj aktivnosti Narodne omladine Srbije, AJ, 114-97. 
Mada higijensko-prosvetni napori vlasti na unapređenju seoske kulture življenja nisu uvek davali očekivane rezultate, što zbog nesistematičnosti, povremenosti i neprilagođenosti modela prosvećivanja seoskim potrebama i uslovima, što zbog sveopšteg siromaštva, konzervativizma i tradicionalizma žitelja ruralnih regiona - modernizacijski procesi, započeti na izmaku međuratnog razdoblja, sporo i neprimetno nastavljeni su i u novim, socijalističkim okolnostima. Ubrzana deagrarizacija, zapošljavanje velikog broja seljaka u industrijskim postrojenjima širom Jugoslavije, sve češći odlazak dece sa sela u grad na školovanje, kao i urbanizacijski procesi u celini, doprineli su prodiranju nekih gradskih običaja i navika u seoske domove, doduše u izmenjenom i prilagođenom obliku. U uslovima povećane socijalne mobilnosti, nekvalifikovani radnici sa sela, preko noći zapošljeni u privredi, postali su istovremeno nosioci urbanizacije u svojim nekadašnjim sredinama, ali i ruralizacije gradova. Najveće promene su bile vidljive u domovima polutana, seljaka - radnika, koji su zahvaljujući novoj delatnosti brzo napuštali tradicionalna shvatanja, unapređivali higijenske navike, radije se u slučaju bolesti obraćali lekaru, donosili novu kulturu na selo i napuštali oskudan, ali ustaljen način ishrane. ${ }^{96}$

I pored znatnih promena i vidljivog napretka, uticaj grada je u prvoj posleratnoj deceniji bio više formalan nego suštinski. Kreveti, drveni podovi, šporeti, ali i varoški inventar - fabrički nameštaj, tepisi, prve zavese, stolnjaci i čaršafi koji je u srpske seoske domove, posebno one u blizini gradova i saobraćajnih komunikacija, počeo ulaziti početkom 50 -ih godina, ${ }^{97}$ predstavljao je nemerljiv, ali ne i dovoljan civilizacijski iskorak iz vekovne bede. Konfekcijska odeća i cipele, umesto nošnje i opanaka, stvarali su pogrešnu sliku o dometima modernizacijskih procesa, budući da „higijenski uslovi života sela“ nisu bili u skladu „sa najlon čarapama, visokim štiklama i savremenom gradskom odećom" koju je bilo moguće „,videti na svakom koraku“. ${ }^{98}$ Estetske promene na srpskim selima vešto su skrivale stare navike i tradicionalan stil življenja. Seoska arhitektura je napredovala, kuće su postajale udobnije i modernije, ali se i dalje dešavalo da se „u proleće mali jaganjci drže u sobi, a namirnice i ostava u staji“ “99 Promene u ishrani bile su minimalne, a i način privređivanja je ostao gotovo neizmenjen - traktori su što zbog cene, što zbog neekonomičnosti upotrebe na malom posedu, korišćeni sporadično, potrošnja veštačkog đubriva je bila zanemarljiva, a žitarice su, kao glavna poljoprivredna kultura, i dalje dominirale na srpskim poljima. ${ }^{100}$

I dok se u gotovo svim segmentima života jednog domaćinstva osećao kakav-takav boljitak i napredak, konzervativni i patrijarhalni nazori seoskog življa, kao i otpor promenama, najviše su dolazili do izražaja u porodičnim odnosi-

\footnotetext{
${ }^{96}$ C. Kostić, Seljaci-industrijski radnici, Beograd 1955, 230-233.

${ }^{97}$ Izveštaj sreskog odbora AFŽ Prokuplje, AJ, 141-13-70.

${ }^{98}$ Uspon Štrpca u posleratnom periodu, AJ, 114-97.

${ }^{99}$ Б. М. Томић, Хигијенски проблеми села (Босиљградски срез), Београд 1954, 23.

${ }^{100}$ Jugoslavija 1918-1988, Beograd 1988, 225, 208.
} 
ma, koji su ostajali nepromenjeni uprkos povoljnijoj društvenoj klimi i većim mogućnostima za ekonomsko osamostaljenje žena. One su, a u mnogim krajevima i deca, živele na marginama seoskih zajednica, bez bilo kakvih prava ili uvažavanja. Posebna zaostalost vladala je u selima južne Srbije gde su devojke radi udaje otimane, a deca masovno prodavana imućnijim seljacima kako bi, za bednu nadoknadu i oskudan obrok, nadničila na tuđem imanju, obično od Đurđevdana do Mitrovdana. ${ }^{101}$ Verovalo se da žena treba ,da vodi kuću i pazi muža i decu, a što manje zna, utoliko je bolja domaćica“, ${ }^{102}$ pa je prosvećivanje seljanki nailazilo na neodobravanje i nelagodnost. Seosku devojku je trebalo što pre udati, a glavni „kvaliteti“ jedne udavače, prema shvatanjima u valjevskom kraju, bili su rana mladost, „poštenje“", kao i kuvarsko i krojačko umeće. ${ }^{103} \mathrm{U}$ novom domu, žena je tretirana pre svega kao radna snaga, nije imala pravo na predah ni na odmor, pa čak ni na bolest. Sama i uglavnom nezaštićena, često je morala da trpi batine ne samo muža ${ }^{104}$ nego i ostalih ukućana. ${ }^{105}$

Seoski brak, shvatan kao čisto ekonomska kategorija i interesna institucija, ženi nije nužno garantovao nikakvu sigurnost i stalnost, budući da je bio podložan raskidu, zbog bolesti ili pak neplodnosti za koju je, po pravilu, uvek ,okrivljavana“ supruga. „Jeste, mi smo je uzeli“, govorila je jedna svekrva o bolesnoj snahi na brakorazvodnoj parnici, ,al beše onda dobro živinče. Radila je bogami dve godine dana. Al posle se isturi nešto, pa sad neće da radi“ ${ }^{106}$ U slučaju razvoda žena je ostajala bespomoćna - bez ikakvog imetka, ${ }^{107}$ bez alimentacije, ${ }^{108}$ potpuno zavisna od dobre volje roditelja i braće. Dešavalo se da jednom „udomljenu“ ženu više neće ni otac ni majka da prime nazad. ${ }^{109} \mathrm{U}$ patrijarhalnom društvu, razvod je za žene sa sela mogao značiti ne samo gubitak muža i ekonomskih sredstava već i dece, budući da roditelji nisu uvek želeli da u dom prime i unuke. Štaviše, surovu porodičnu tradiciju verifikovali su i sudovi, koji su, uzimajući u obzir realnost i seoske prilike, počeli dosuđivati decu ocu. ${ }^{110}$ Paradoksalno, uticaj deagrarizacije i urbanizacije na porodične odnose ženi sa sela je umesto olakšanja stvorio dodatne probleme, učinivši njen položaj u braku još nesigurnijim. Naime, uključivanje velikog broja seljaka u industriju i njihov prelazak u gradove prouzrokovao je sve češće raspadanje seoskih brakova uglavnom

${ }^{101}$ Neka zapažanja o selima sreza Priština i Vranja, AJ, 114-97.

102 Isto.

${ }^{103}$ Neki materijali o kulturno-prosvetnoj aktivnosti Narodne omladine Srbije, AJ, 114-97.

${ }^{104}$ Izveštaj ekipe iz sela Dupljaja, AJ-13-70; Informacija o nekim problemima porodice (Rađena na osnovu materijala sa savetovanja društvenih organizacija), AJ, 142-17-50.

${ }^{105}$ Зашто се разводе бракови, НИН, 3. октобар 1954.

106 Зашто се разводе сеоски бракови, НИН, 18. децембар 1955.

107 Зашто се разводе сеоски бракови, НИН, 3. октобар 1954.

${ }^{108}$ Zapisnik sa sastanka Komisije za rad među ženama Saveznog odbora SSRNJ održan 3. februara 1955, AJ, 142-90-402.

${ }^{109}$ Положај жене на селу, Жена данас, 112, 1953.

${ }^{110}$ Zapisnik sa sastanka Komisije za rad među ženama Saveznog odbora SSRNJ održan 3. februara 1955, AJ, 142-90-402. 
usled „muževljevog saživljavanja sa nekom ženom u gradu“. ${ }^{111}$ Razvodi od nepismenih i od posla ogrubelih seljanki naročito su uzimali maha među oficirima ${ }^{112} i$ partijskom elitom u formiranju. ${ }^{113}$ Time su „stari“ život i seljačko poreklo i simbolično brisani i poništavani raskidom braka - poslednjom vezom „nove klase“ sa seoskom bedom i nesrećom. Potresna sudbina ostavljenih žena našla je svoje mesto u Ćopićevoj Osmoj ofanzivi, a lik Ruže, nedovoljno otmene za grad i osuđene na život u ličkoj zabiti, postao je personifikacija jednog vremena, ali i načina uzdizanja vladajuće elite.

Srpsko selo je bilo višedecenijski talac ne samo svoje zaostalosti nego i nemerljivog siromaštva. Partijski snovi o preobražaju i modernizaciji, prosvetni i domaćički tečajevi i zdravstveno-higijensko prosvećivanje - ma koliko sporadični i nesistematski - bili su u dubokoj koliziji sa zvaničnom ekonomskom politikom prema selu. Obavezni otkup i nasilna kolektivizacija, ogromni porezi i zemljišni maksimum, strah od „kulaka“, „tezaurisanog seljačkog novca“" i seoskog bogaćenja, sputavali su i onemogućavali modernizaciju i mehanizaciju proizvodnje, svodeći seljaka na večitog naturalnog proizvođača. U takvim okolnostima, pri velikoj skupoći industrijske robe, čak i ako je postojala svest o potrebi unapređenja životnih prilika nije bilo lako naći novac za renoviranje kuće ili kupovinu novog nameštaja. O skromnim dometima modernizacijskih promena i stepenu unapređenja kulture življenja, neumoljivo je svedočila i zvanična statistika. Relativno visoka stopa nataliteta, kratak životni vek, velika smrtnost dece, sporadična elektifikovanost sela, ${ }^{114}$ zagađeni bunari, zemljani podovi ${ }^{115}$ i otvorena ognjišta ${ }^{116}$ i krajem 1955. godine predstavljali su jedinu poznatu svakodnevicu najvećeg broja srpskih seljaka. Zapostavljanje i zaostajanje sela nastavljeno je i u narednim godinama, pa je i tokom 60-ih i 70-ih, uprkos odmakloj društvenoj modernizaciji, veliki broj seljaka živeo u trošnim kućama, od kojih čak $20 \%$, prema podacima iz 1971. godine, nije imalo ni električnu ni vodovodnu instalaciju. ${ }^{117}$

111 Зашто се разводе сеоски бракови, НИН, 3. октобар 1954; Zapisnik sa sastanka Komisije za rad među ženama Saveznog odbora SSRNJ održan 3. februara 1955, AJ, 142-90-402.

${ }^{112}$ Prijem delegacije IV kongresa AFŽ kod predsednika Tita u Beogradu 28. septembra 1953, A JBT, KPR II-2.

${ }^{113}$ Zapisnik sa sastanka CK KP Srbije održanog 29. juna 1945, AS, Đ2 - Politbiro (bez broja) -1 .

${ }^{114}$ M. Petrović, Elektrificiranost poljoprivrednih domaćinstva, Sociologija sela, 2, $1963,54$.

${ }^{115}$ Podaci o kvalitetu prostorija za stanovanje seoskih domaćinstva - u procentima, AJ, 114-96.

${ }^{116}$ P. Marković, Promene u uslovima stanovanja na selu. Razdoblje 1900-1960, Sociologija sela, 4, 1964, 11.

${ }^{117}$ S. Vujović, Stambena kriza i ljudske potrebe, Sociologija, 4, 1979, 452; V. Pešić, Društvena slojevitost i stil života, Društveni slojevi i društvena svest, Beograd 1977, 135. 
Ivana Dobrivojević

\author{
THE IMAGE OF THE SOCIETY \\ LIVING CONDITIONS IN SERBIAN VILLAGE 1945-1955
}

\begin{abstract}
Summary
Historical circumstances and the unequal economic development represented the main causes of the significant regional differences in the life standard and cultural habits of Serbian peasants. However, despite of considerable regional disparities, widespread poverty, the miserable housing conditions, poor diet, lack of personal and communal hygiene, ignorance and primitive folk customs shaped the gloomy reality of Serbian peasantry. Slow modernization processes, that started during the 1930 - ies, where stopped during the war. Immediately after the liberation the new authorities try to educate the villagers, both practically and ideologically. Literacy courses, along with basic tips on home maintenance, meal preparation and bringing up of infants represented the core educational activities that were supposed to lead to the improvement of the living conditions on Serbian villages. However, centuries-old backwardness could not be easily uprooted and eradicated. Moreover, the modest level of education of Party officials, along with strict dogmatic views and declarative enthusiasm of Party activists could not lead to the genuine modernization. Thus, educational efforts were never systematic - authorities were not prepared to invest scares financial resources in education and life standard, since the political and economic priority always was recognized in heavy industry. Furthermore, it fell to the local Party officials to become leaders of modernization processes in socialist Yugoslavia.

Paradoxically, beliefs and lifestyle of those "modernizers" was in no way different from other villagers. In such circumstances, old patriarchal norms were slowly being abandoned. Conservatism and stubborn insistence on the experience of the ancestors caused the opposition to any "novelty", especially in the poorest areas. It turned out that the housekeeping courses could not impose significant changes in the peasant family lifestyle. Many village girls, despite the successful completion of the course, were compelled to run the household in the old, traditional way, since their parents were strongly opposing the novelties. However, rapid deagrarianization, the employment of a large number of farmers in the industry along with a growing number of school children from villages and urbanization processes in general, had to contribute to the penetration of some urban customs and habits. However, in the first postwar decade, the impact of the modernization to the rural lifestyle was more formal than substantial. Although the hygiene slightly improved and the peasant population slowly abandoned traditional clothing and purchased new furniture, traditional habits and the "old" style of living prevailed. Infant mortality was still high, the patriarchal family hierarchy untouched, farming primitive and diet poor and unhealthy.
\end{abstract}

